\title{
Effects of Land Use Change, Cultivation, and Landscape Position on Prairie Soil Organic Carbon Stocks
}

\author{
Ronald K. Salemme1, Kenneth R. Olson'1, Alexander N. Gennadiyev², Roman G. Kovach ${ }^{2}$ \\ ${ }^{1}$ Department of Natural Resources and Environmental Science, University of Illinois at Urbana-Champaign, Urbana, IL, USA \\ ${ }^{2}$ Lomonosov Moscow State University, Moscow, Russia \\ Email: krolson@illinois.edu
}

How to cite this paper: Salemme, R.K., Olson, K.R., Gennadiyev, A.N. and Kovach, R.G. (2018) Effects of Land Use Change, Cultivation, and Landscape Position on Prairie Soil Organic Carbon Stocks. Open Journal of Soil Science, 8, 163-173. https://doi.org/10.4236/ojss.2018.87013

Received: May 4, 2018

Accepted: July 7, 2018

Published: July 10, 2018

Copyright ( 92018 by authors and Scientific Research Publishing Inc. This work is licensed under the Creative Commons Attribution International License (CC BY 4.0).

http://creativecommons.org/licenses/by/4.0/ (c) (i) Open Access

\begin{abstract}
Temperate grassland soils are typically a sink for carbon. However, it is estimated that up to $99 \%$ of tallgrass prairies in North America have been converted to another land use. These conversions can lead to increased soil erosion and soil organic carbon (SOC) mineralization rates, turning a large carbon sink into a source. The purpose of this study was to compare by land use the retention of SOC, TSN, and fly ash on sloping landscapes with an emphasis on measuring the subsoil in addition to the surface soil. Eight paired plots were established on adjacent, sloping landscape profiles in western Iowa; one site a cropland and the other a remnant tallgrass prairie. The prairie landscape had a baseline SOC stock of $232 \mathrm{Mg}-\mathrm{C} \mathrm{ha}{ }^{-1}$. After roughly 150 years of agriculture the cropland had 52\% less SOC, 39\% less TSN, and 22\% less fly ash which equates to annual losses of $0.55 \mathrm{Mg}-\mathrm{C} \mathrm{ha} \mathrm{yr}^{-1}, 0.04 \mathrm{Mg}-\mathrm{N} \mathrm{ha} \mathrm{yr}^{-1}$, and $0.0002 \mathrm{Mg}$-fly ash $\mathrm{ha}^{-1} \mathrm{yr}^{-1}$.
\end{abstract}

\section{Keywords}

Soil Organic Carbon, Soil Erosion, Land Use Change, Tallgrass Prairie

\section{Introduction}

Temperate grasslands are one of the most converted and least-protected biomes worldwide and the tall-grass prairies of North America are no exception, with estimated loss of $82 \%$ - $99 \%$ since the time of settlement [1] [2]. When a prairie is converted to agricultural use the accompanying changes in vegetative cover and management practices can have severe negative impacts on soil organic carbon (SOC) stocks, largely through increases in soil erosion and SOC minera- 
lization [3] [4]. While the effects of land use conversion to agriculture have been widely studied, the results of such studies have been quite variable and far too often these studies soil sampling depth are limited to the upper $10-20 \mathrm{~cm}$ of the soil. As demand for arable land increases, the conversion of marginal lands becomes common place; this makes it critical that we continue to improve our understanding of the effects of cultivation on SOC stock in sloping landscapes.

Temperate grasslands are typically found to be a sink for carbon and soils in North American grasslands have been shown to sequester anywhere from 0.20 to $0.58 \mathrm{Mg}-\mathrm{C} \mathrm{ha}^{-1} \mathrm{yr}^{-1}$ [5] [6] [7]. The dense surface cover found in grasslands protects the soil from wind and water erosion while contributing to belowground carbon through root turnover and exudates. Additionally, studies have found that areas with high species diversity, such as temperate grasslands, also experience higher SOC storage via increased microbial activity [8]. Following cultivation, species composition tends to be much more homogenous and surface cover is often greatly reduced during the non-growing season leaving areas susceptible to physical erosion. Tillage can exacerbate the effects of reduced surface cover by breaking down soil aggregates [3] and it can also increase SOC mineralization rates [4] [9]. Following conversion to cropland, estimates of SOC stock losses range from no change at all [10] to losses of $60 \%$ [11]. This suggests there is still uncertainty regarding changes in SOC stocks and soil erosion after land use conversion.

The goal of this research is to measure the differences in surface and subsoil SOC, total soil nitrogen (TSN), and soil erosion between soil catena's at a remnant-tallgrass prairie and an adjacent cropland. Fly ash mass will be measured to assess soil erosion. Fly ash is spherical magnetic particles previously emitted from coal burning power plants, trains, and farm equipment. Fly ash have previously been used as tracers in several soil erosion studies because it is persistent in the soil and its spherical shape and magnetic susceptibility make fly ash easily identifiable and separable [12] [13] [14]. Our hypothesis is that conversion of prairie to cropland, and the associated change in vegetative cover and management practices would result in significantly less SOC, TSN, and fly ash for both the surface soil and the subsoil. The one exception to this would be the subsoil for depositional areas which could have increased levels of SOC, TSN, and fly ash resulting from sediment deposition from up slope areas. The results of this research will help improve global C models and contribute baseline SOC data for use in other land use change studies or restoration efforts.

\section{Materials and Methods}

The study site is located at the Dinesen Prairie in Shelby County, Iowa approximately $7 \mathrm{~km}$ northeast of the city of Harlan (Figure 1; $41.708919^{\circ},-95.280461^{\circ}$ ). The soils in the area fine-silty, mixed, superactive, mesic Typic Hapludolls derived from loess such as the Marshall or Exira soil series. The mean annual precipitation for the area is $84.7 \mathrm{~cm}(33.4 \mathrm{in})$ and mean annual temperature is $8.6^{\circ} \mathrm{C}\left(47.6^{\circ} \mathrm{F}\right)$. Two land use types were used for this study, prairie and agriculture, both on 


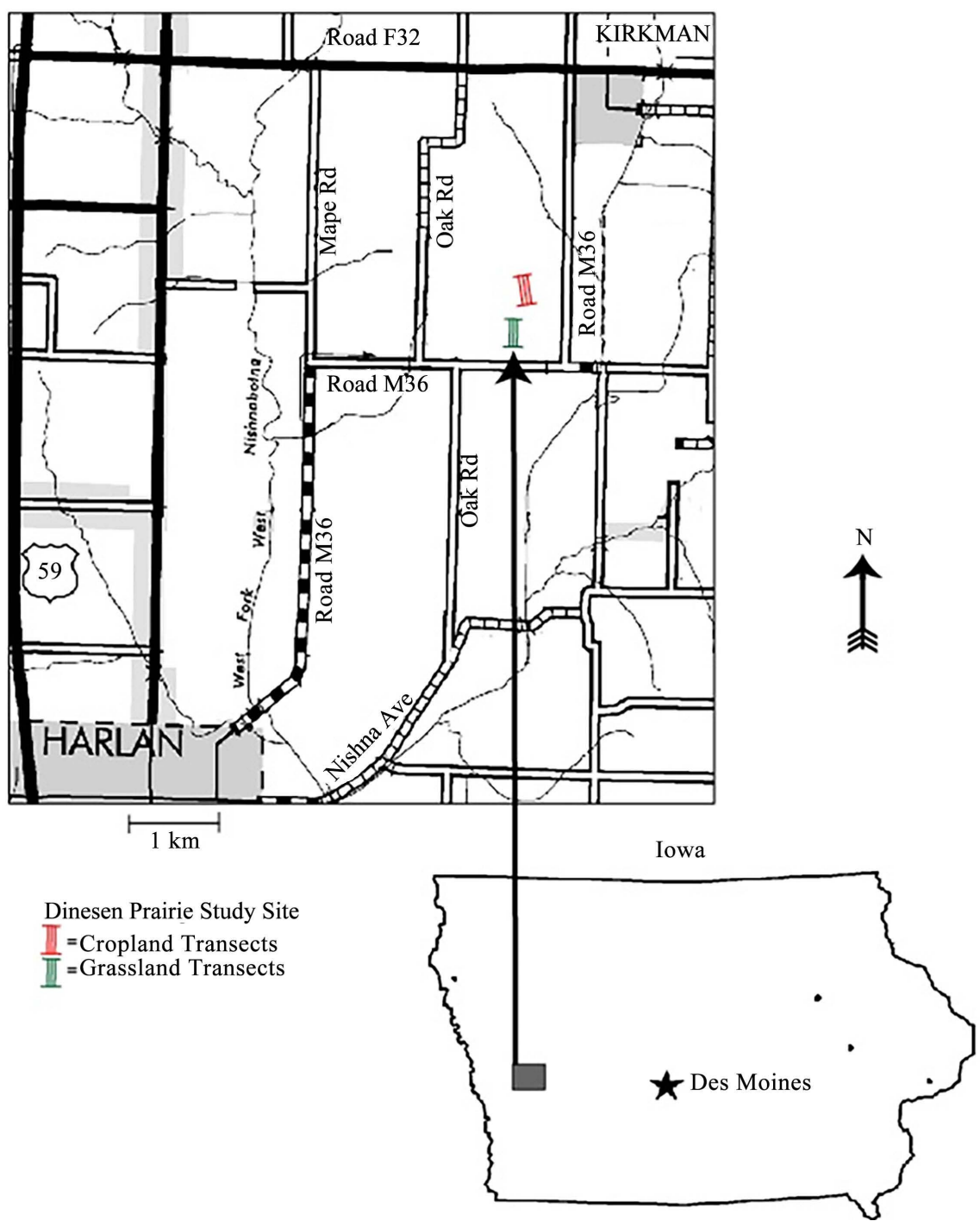

Figure 1. A map of the crop and prairie treatments used at the Dinesen Prairie study site in Shelby County, Iowa near the town of Harlan $\left(41.708919^{\circ},-95.280461^{\circ}\right)$. In July of 2015 three paired transects were established on two adjacent, south-facing sites; one being a cropland and the other a remnant tallgrass prairie. Modified from Olson et al. [20].

adjacent, sloping, south facing landscapes. A monument marker placed at the prairie site in 1946 claims that the area has no history of being plowed. However, the area was seeded with legumes at some point and was likely used for grazing in the past. Presently, controlled burns are used to manage the prairie in years when weather permits and the area is generally mowed in the fall. The vegetation at the prairie site is dominated by smooth brome (Bromus inermis) and big bluestem (Andropogon gerardii), which account for over 50\% of the surface cover. The crop site utilizes a corn and soybean rotation and no-till management.

\section{Field and Laboratory Methods}

Soil samples were collected in July of 2015 using a similar design as used by Ol- 
son et al. [15]. This consisted of three parallel transects spaced $10 \mathrm{~m}$ apart running down a soil catena for each land use type. Each transect was sampled at the summit (SU), shoulder (SH), upper backslope (UBS), lower backslope (LBS), footslope (FS), and toeslope (TS). Figure 2 shows the landscape cross-sections and the plot locations for each site. A soil core was collected at each landscape position to a depth of $1 \mathrm{~m}$ which was segmented into intervals of: $0-15 \mathrm{~cm}, 15-$ $30 \mathrm{~cm}, 30-50 \mathrm{~cm}, 50-75 \mathrm{~cm}$, and $75-100 \mathrm{~cm}$. For each land use type, a second soil core was collected to a depth of $50 \mathrm{~cm}$ at each landscape position along the middle transect before being segments into increments of $0-15 \mathrm{~cm}, 15-30 \mathrm{~cm}$, and $30-50 \mathrm{~cm}$ for fly ash testing. The samples were air-dried and crushed to pass a 2-mm sieve prior to lab testing. Bulk density samples were also collected at each sampling position and depth using a Model 200 soil core sampler (Soil Moisture Equipment Corp).

Fly ash testing was completed at Moscow State University (Russia) using a modified Gouy balance and methods developed by Olson et al. [16] [17]. SOC stocks were determined using a modified version of the Walkley-Black wet oxidation method [18]. TSN was measured using a diffusion modified semi-micro Kjeldahl method, based on procedure number [18]. In both cases each sample was analyzed in duplicate and the data averaged.

\section{Statistical Methods}

Statistical analysis was done using R version 3.4.4. Linear mixed models (LMMs,
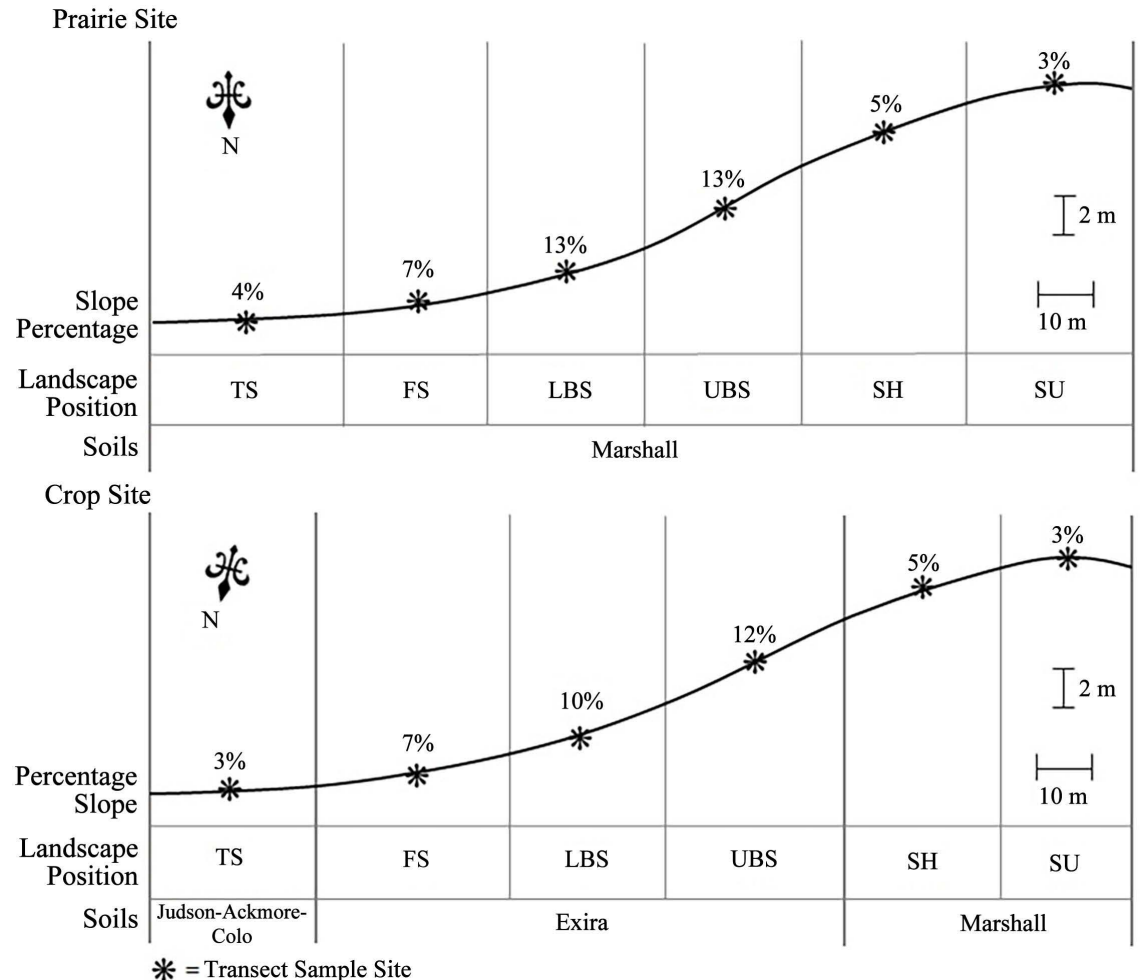

Figure 2. Landscape profiles for the prairie (top) and crop (bottom) treatments at the Dinesen Prairie site. Both sites have similar slopes, aspects, soil textures, and soil $\mathrm{pH}$. 
lmer function in R) were used to determine the effects of land use type and landscape position on SOC and TSN stocks in the surface and subsoil for the two land use types. To account for the paired design and any potential spatial dependencies, plot pairs as well as landscape position nested in land use type were included as random effects in the model. The same random effects were used to determine how SOC is affected by land use type and the interaction of soil depth and landscape position. LMMs were also used to compare the levels of fly ash between land use types using plot pairs as a random effect. Multiple comparisons with a Tukey adjustment were used to determine significant difference between landscape positions. In all instances an alpha of 0.05 was used to declare significance and 0.10 for marginal significance.

\section{Results}

SOC mass was determined by scaling the SOC concentrations by soil bulk density. Figure 3(a) and Figure 3(b) show the results for surface and subsoil SOC mass by land use type and landscape position. The prairie site had significantly higher SOC levels than the cropland site for both the surface and subsoils (p-value $=0.0003$ and $0.0161, \mathrm{R}^{2}=0.88$ and 0.93 respectively) regardless of landscape position, with the exception of the subsoil of the TS [19]. Within a land use type there were no significant differences seen between landscape positions although the TS had marginally higher SOC and TSN ( $\mathrm{p}$-value $=0.0617$ and 0.0961 , respectively) than the other positions for both sites. The average proportion of surface SOC to total SOC to $1 \mathrm{~m}$ depth was 31\% (SE $\pm 5 \%$ ) and did not significantly vary by land use type or by landscape position, although there was a trend for both land use types to have the highest proportion of surface SOC in erosional areas and the lowest proportion in the TS [20].

Figure 4 shows the relationship between SOC and depth for the two land use types. SOC was strongly correlated with land use type ( $\mathrm{p}$-value $=0.0140)$ and the interaction of soil depth and landscape position ( $\mathrm{p}$-value $\leq 0.0001, \mathrm{R}^{2}=0.87$ ). The prairie site maintained higher levels of SOC than the cropland throughout the entire $1 \mathrm{~m}$ sampling depth with the exception of the TS where the cropland had increasing SOC stock with depth.

TSN mass was highly correlated with SOC for both land use types, $\left(\mathrm{R}^{2}=0.99\right.$ for cropland and 0.78 for the prairie) and as a result TSN followed similar trends as SOC. The prairie site had significantly greater levels of TSN across the entire landscape in both the surface and subsoils ( $\mathrm{p}$-value $=0.0009$ and $0.0498, \mathrm{R}^{2}=$ 0.87 and 0.91 respectively) (Figure $3(\mathrm{c})$ and Figure $3(\mathrm{~d})$ ). All landscape positions at the prairie site had greater TSN in the surface soil; however, subsoil TSN was only marginally higher than the cropland when viewed by landscape position. Within a land use type TSN mass was the same at all landscape positions except for the TS which again had marginally higher TSN in the subsoil (p-value $=0.0757)$. C:N ratios between treatments were also significantly different regardless of landscape position, with an average ratio of 12.2:1 for the prairie site and 8.8:1 for the crop site ( $\mathrm{p}$-value $\left.=0.0029, \mathrm{R}^{2}=0.92\right)$. 


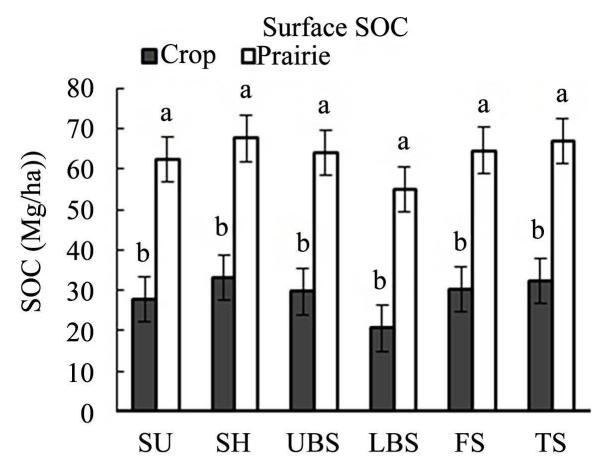

(a)

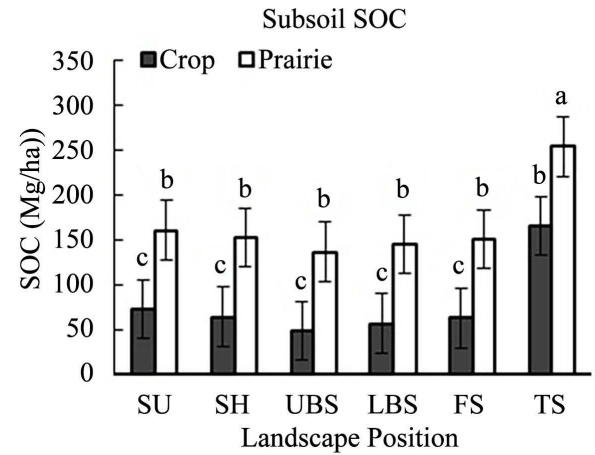

(b)

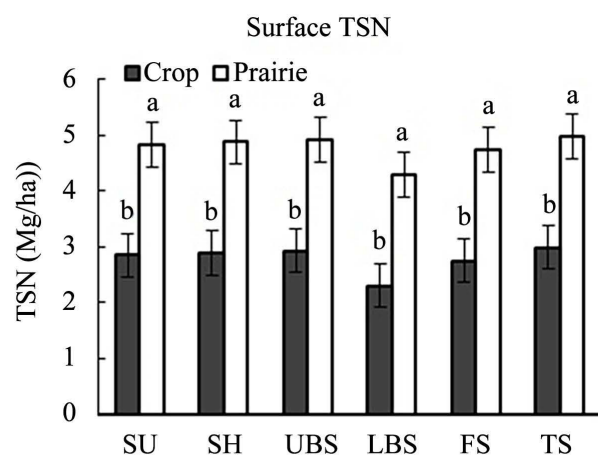

(c)

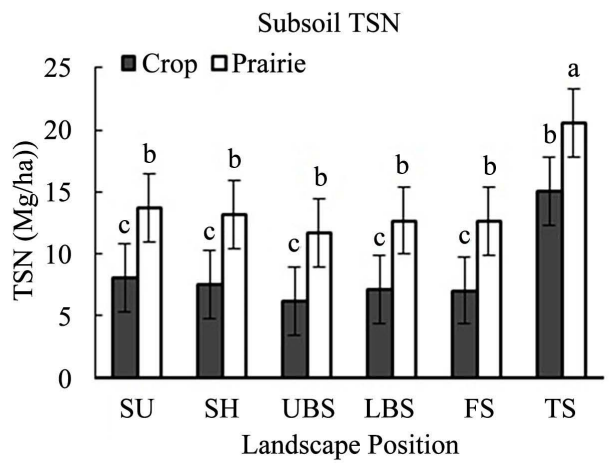

(d)

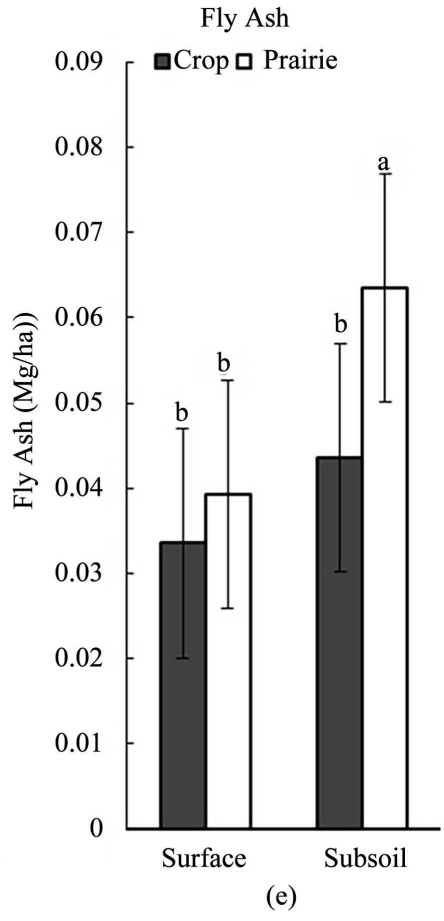

Figure 3. SOC and TSN mass as a function of land use type and landscape position for the surface soil (a and c, $0-15 \mathrm{~cm})$ and subsoil (b and d, $15-100 \mathrm{~cm}$ ) at the Dinesen study sites. Fly ash mass (e) by land use type for the surface soil $(0-15 \mathrm{~cm})$ and subsoil $(15-50 \mathrm{~cm})$. All figures are mean \pm standard error. The prairie site had significantly greater levels of SOC and TSN in the surface and subsoil across all landscape position with the exception of subsoil TSN which was only marginally higher for the prairie site. Within a land use type there were no significant differences seen between landscape positions except for the subsoil in the TS which had marginally higher SOC and TSN ( $\mathrm{p}$-value $=0.0617$ and 0.0757 , respectively) than the other positions. Fly ash, a tracer for physical soil erosion, was significantly higher in the prairie subsoil ( $\mathrm{p}$-value $=0.0181, \mathrm{R}^{2}=0.852$ ), but the surface soils retained similar levels $(\mathrm{p}$-value $=0.5828)$.
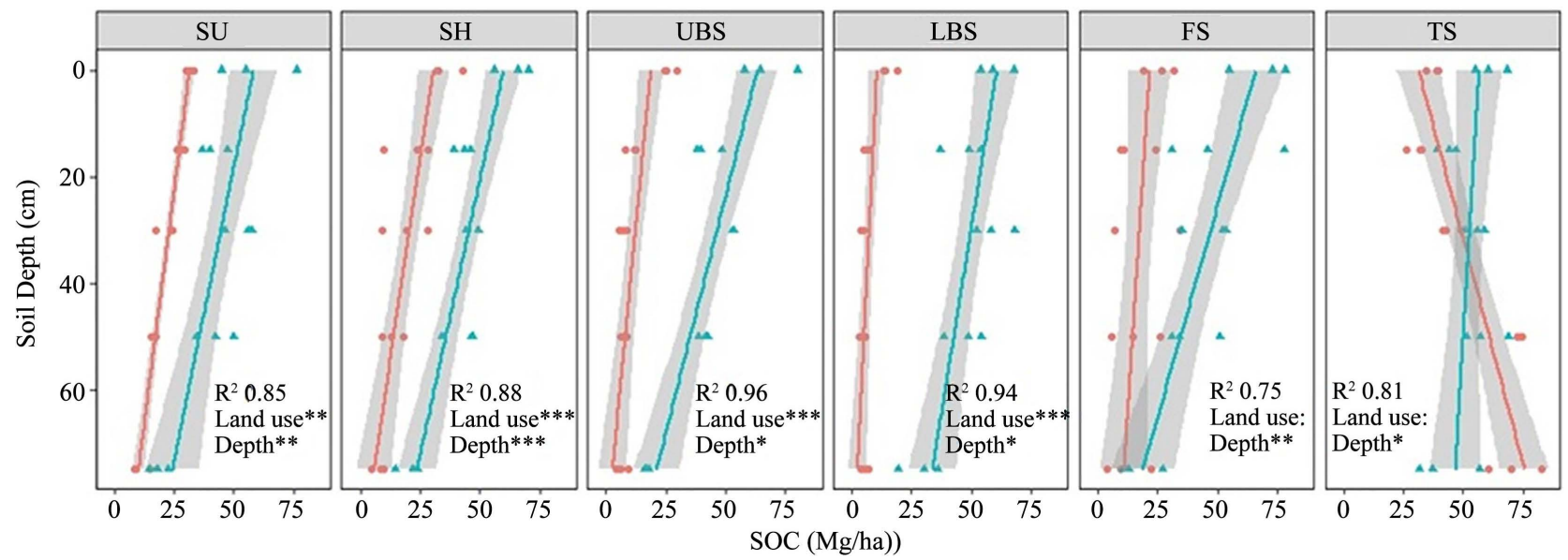

Figure 4. For a given landscape position, SOC mass was highly correlated with land use type and soil depth. The prairie site maintained higher levels of SOC than the cropland throughout the entire $1 \mathrm{~m}$ sampling depth with the exception of the TS where the cropland had increasing SOC with depth. This is likely due to the erosion of SOC rich topsoil from upslope being deposited in the depositional areas. There was an interactive effect between land use type and depth for the FS and TS, for the other landscape positions there was an additive effect. ${ }^{*},{ }^{* *}$, and ${ }^{* *}$ signify statistical difference at p-values of $0.05,0.01$, and 0.001 respectively. The shaded areas represent mean standard error. 
Fly ash could only be statistically analyzed at the landscape level since there was only one transect used per land use type. Both sites had similar levels of fly ash in the surface soil, $0.036 \mathrm{Mg} \mathrm{ha}^{-1}$ (p-value $=0.5828$ ). However, the prairie site did have $31 \%$ higher fly ash mass in the subsoil (0.064 vs. $0.043 \mathrm{Mg} \mathrm{ha}^{-1}$, $\mathrm{p}$-value $=0.0181, \mathrm{R}^{2}=0.852$ )

In order to compare the differences in SOC, TSN, and fly ash retention for the entire landscape profile, which had slightly different slope lengths, the mass data was weighted by landscape segment length (Table 1). After 150 years of cultivation, the cropland retained about $48 \%$ of the SOC that is currently found in the grassland, with upslope areas losing an average of $60 \%$ SOC and depositional areas losing $44 \%$ SOC. This equates to a loss of $120.91 \mathrm{Mg}-\mathrm{C} \mathrm{ha}^{-1}$ overall or 0.55 $\mathrm{Mg}-\mathrm{C} \mathrm{ha} \mathrm{yr}^{-1}$. For TSN, cultivation resulted in losses of $39 \%$, which is equal to $7.40 \mathrm{Mg}-\mathrm{N} \mathrm{ha}{ }^{-1}$ overall or $0.04 \mathrm{Mg}-\mathrm{N} \mathrm{ha}{ }^{-1} \mathrm{yr}^{-1}$. The fly ash data can provide insight on changes since roughly 1910, when coal powered trains and farm equipment became commonplace; and in that time the cropland lost $22 \%$ of the fly ash mass compared to the prairie site. Upslope landscape positions accounted for fly ash losses of $39 \%$ while the TS saw an increase of $21 \%$.

Table 1. SOC mass (mean + standard deviation) at the Dinesen Prairie site for the entire landscape profile weighted by segment length (Modified from Salemme [19]; Olson et al. [20]).

\begin{tabular}{|c|c|c|c|c|c|}
\hline & Mass of SOC & Landscape & Landscape & Landscape segment & Loss from \\
\hline Landscape & to $1 \mathrm{~m}$ depth & Sediment & Segment \% & weighted SOC & conversion \\
\hline Position & (Mg-C/ha) & Length (m) & of Transect & (Mg-C/ha) & $(\%)$ \\
\hline \multicolumn{6}{|l|}{ Prairie Site } \\
\hline Summit & $222.94(8.79) \mathrm{a}$ & 26.70 & 0.15 & $33.96(1.34) \mathrm{a}$ & \\
\hline Shoulder & $219.91(11.42) \mathrm{a}$ & 30.60 & 0.17 & 38.39 (1.99)a & \\
\hline U. Backslope & $200.58(7.51) \mathrm{a}$ & 31.30 & 0.18 & $35.81(1.34) \mathrm{a}$ & \\
\hline L. Backslope & $199.75(16.64) a$ & 26.10 & 0.15 & $29.74(2.48) \mathrm{a}$ & \\
\hline Footslope & $215.47(27.11) \mathrm{a}$ & 27.20 & 0.16 & $33.43(4.21) \mathrm{a}$ & \\
\hline Toeslope & $320.59(21.62) \mathrm{a}$ & 33.40 & 0.19 & $61.08(4.12) \mathrm{a}$ & \\
\hline Total & $1379.24(23.84)$ & 175.30 & & $232.41(6.22)$ & \\
\hline \multicolumn{6}{|l|}{ Crop Site } \\
\hline Summit & $100.14(6.18) b$ & 22.90 & 0.14 & $13.56(0.84) \mathrm{b}$ & -0.60 \\
\hline Shoulder & $99.11(22.40) \mathrm{b}$ & 27.00 & 0.16 & $15.51(3.58) b$ & -0.60 \\
\hline U. Backslope & $77.77(6.55) \mathrm{b}$ & 30.00 & 0.18 & $13.80(1.16) b$ & -0.61 \\
\hline L. Backslope & $76.95(2.85) \mathrm{b}$ & 26.90 & 0.16 & $12.24(0.45) \mathrm{b}$ & -0.59 \\
\hline Footslope & $92.67(33.00) \mathrm{b}$ & 26.50 & 0.16 & $14.52(5.17) \mathrm{b}$ & -0.57 \\
\hline Toeslope & $197.78(10.76) b$ & 35.80 & 0.21 & $41.87(2.28) \mathrm{b}$ & -0.31 \\
\hline Total & $642.42(73.66)$ & 169.10 & & $111.50(16.44)$ & -0.52 \\
\hline
\end{tabular}

Values with the same letter within a column are not significantly different at the 0.05 probability level. 


\section{Discussion}

As expected, the prairie site had greater levels of SOC in both the surface soil and subsoil across all landscape positions. Overall the prairie site contained 232 $\mathrm{Mg}-\mathrm{C} \mathrm{ha}{ }^{-1}$ to a $1 \mathrm{~m}$ depth compared to $111 \mathrm{Mg}-\mathrm{C} \mathrm{ha}^{-1}$ for the cropland. The 52\% difference in SOC is consistent with a 2001 study that compared the same prairie site with a cropland in an adjacent county which found SOC in the upper $20 \mathrm{~cm}$ of the soil to be $50 \%$ less in the cropland regardless of landscape position [21]. Our study shows that the $50 \%$ estimate continues well into the subsoil and that measuring SOC stocks to a depth of $1 \mathrm{~m}$, rather than just the surface soil, resulted in SOC estimates that were roughly 13 times higher for the entire landscape profile.

Figure 4 shows that the lowest sampling depth, $75-100 \mathrm{~cm}$, is nearing the range where the cropland soil contains only negligible amounts of SOC; with the exception of the TS which actually increased with depth and likely contains SOC beyond a depth of $2 \mathrm{~m}$. For the grassland soils the data suggest that for all landscape positions there is ample SOC even beyond $1 \mathrm{~m}$, suggesting that the $52 \%$ difference in SOC is on the conservative side.

Following conversion to agriculture, it is estimated that natural areas lose roughly $20 \%$ of the SOC present to the atmosphere via SOC oxidation and mineralization and $10 \%$ to surface waters via erosion with the majority of the changes occurring within the first 20 years of conversion [4] [22] [23]. By these estimates, if the Dinesen Prairie site was cultivated there would be a loss of 23 $\mathrm{Mg}-\mathrm{C} \mathrm{ha}{ }^{-1}$ to surface waters and $46 \mathrm{Mg}-\mathrm{C} \mathrm{ha}^{-1}$ to the atmosphere, which has the $\mathrm{CO}_{2}$-equivalent of $170 \mathrm{Mg}-\mathrm{CO}_{2} \mathrm{ha}^{-1}$. Using the SOC sequestration estimates of 0.2 to $0.58 \mathrm{Mg}-\mathrm{C} \mathrm{ha}^{-1} \mathrm{yr}^{-1}$ for North American temperate grasslands, if the cropland was returned to a grassland it would take anywhere from 209 to 605 years to return the cropland SOC stocks to $232 \mathrm{Mg}-\mathrm{C} \mathrm{ha}{ }^{-1}$.

TSN and fly ash followed very similar trends as SOC with the exception of fly ash in the upper $15 \mathrm{~cm}$ being not significantly different between land use types. The rate of loss for SOC was correlated with the change in TSN and fly ash $\left(\mathrm{R}^{2}=\right.$ 0.95 and 0.47 respectively). Our data suggest that even in the absence of soil erosion the conversion of prairie to cropland would result in a loss of $25 \%$ of TSN and $40 \%$ SOC, likely from leaching, microbial activity, and oxidation. This means that SOC is being lost faster than TSN or fly ash and is supported by the lower $\mathrm{C}: \mathrm{N}$ for the cropland compared to the grassland. This trend has been seen in other studies utilizing a corn-soybean rotation as $\mathrm{N}$-fixation from legumes can reduce root-derived $\mathrm{C}$ inputs [8] and $\mathrm{N}$ fertilizer additions can increase the rates of microbial activity and SOC decomposition [24].

This research provides a baseline figure for remnant grassland SOC stocks of $232 \mathrm{Mg}-\mathrm{C} \mathrm{ha}{ }^{-1}$ and found that the conversion to agriculture resulted in a loss of $0.55 \mathrm{Mg}-\mathrm{C} \mathrm{ha}{ }^{-1} \mathrm{yr}^{-1}$ for roughly the last 150 years. Had our soil sampling depth been limited to the $20 \mathrm{~cm}$ surface layer with the assumption that the subsoil was unaffected, we would have greatly underestimated the level of SOC stocks in the 
grassland which stresses the importance of sampling deeper in the soil profile. To continue improving our understanding of land use change effects on SOC stocks future research should focus on how fast and slow pools of SOC are impacted by land use conversion. Also, isotopic natural abundance methods could potentially shed light on the underlying mechanisms driving the changes seen in SOC stock by allowing for comparisons of d13C levels of SOC to those of plantand microbial-derived carbon. Given that demand for arable land will likely lead to an increase in the conversion of marginal lands it is important that we have a thorough understanding of land use change effects so we can make informed land management decisions.

\section{Acknowledgements}

Published with funding support from USDA, Forest Service, McStennis project number 875-908, US State Department (CRDF RUG1-2948-MO-09) and the Director of the Illinois Office of Research, College of Agricultural, Consumer, and Environmental Science, University of Illinois, Urbana, Illinois. Funded by the US Civilian Research and Development Foundation and the Russian Foundation (project \# 10-05-00532) as part of a linkage grant between Faculty of Geography, Moscow State University and NRES, ACES at University of Illinois at Urbana-Champaign. Additional support was provided in the framework of the MSU Faculty of Geography research topic "Natural and Human-Induced Changes of Landscape Geochemic and Soil Systems". A special thanks for the technical services provided by Atlantic Iowa Soil Survey Staff of the USDA, NRCS.

\section{References}

[1] Hoekstra, J.M., Boucher, T.M., Ricketts, T.H. and Roberts, C. (2005) Confronting a Biome Crisis: Global Disparities of Habitat Loss and Protection. Ecology letters, 8, 23-29. https://doi.org/10.1111/j.1461-0248.2004.00686.x

[2] Samson, F. and Knopf, F. (1994) Prairie Conservation in North America. BioScience, 44, 418-421. https://doi.org/10.2307/1312365

[3] Lal, R. (2005) Soil Erosion and Carbon Dynamics. Elsevier, Amsterdam.

[4] Gregorich, E., Greer, K., Anderson, D. and Liang, B. (1998) Carbon Distribution and Losses: Erosion and Deposition Effects. Soil and Tillage Research, 47, 291-302. https://doi.org/10.1016/S0167-1987(98)00117-2

[5] Jones, M. and Donnelly, A. (2004) Carbon Sequestration in Temperate Grassland Ecosystems and the Influence of Management, Climate and Elevated $\mathrm{CO}_{2}$. New Phytologist, 164, 423-439. https://doi.org/10.1111/j.1469-8137.2004.01201.x

[6] Conant, R.T., Paustian, K. and Elliott, E.T. (2001) Grassland Management and Conversion into Grassland: Effects on Soil Carbon. Ecological Applications, 11, 343-355. https://doi.org/10.1890/1051-0761(2001)011[0343:GMACIG]2.0.CO;2

[7] Bruce, J.P., Frome, M., Haites, E., Janzen, H., Lal, R. and Paustian, K. (1999) Carbon Sequestration in Soils. Journal of Soil and Water Conservation, 54, 382-389.

[8] Lange, M., Eisenhauer, N., Sierra, C.A., Bessler, H., Engels, C., Griffiths, R.I., Mellado-Vázquez, P.G., Malik, A.A., Roy, J. and Scheu, S. (2015) Plant Diversity In- 
creases Soil Microbial Activity and Soil Carbon Storage. Nature Communications, 6, 6707. https://doi.org/10.1038/ncomms7707

[9] Reicosky, D. (2002) Long-Term Effect of Moldboard Plowing on Tillage-Induced $\mathrm{CO}_{2}$ Loss. In: Kimble, J.M., Lal, R. and Follett, R.F., Eds., Agricultural Practices and Policies for Carbon Sequestration in Soil, CRC Press, Boca Raton, 87. https://doi.org/10.1201/9781420032291.ch8

[10] Wang, J., Fu, B., Qiu, Y. and Chen, L. (2001) Soil Nutrients in Relation to Land Use and Landscape Position in the Semi-Arid Small Catchment on the Loess Plateau in China. Journal of Arid Environments, 48, 537-550. https://doi.org/10.1006/jare.2000.0763

[11] Guo, L.B. and Gifford, R. (2002) Soil Carbon Stocks and Land Use Change: A Meta Analysis. Global Change Biology, 8, 345-360. https://doi.org/10.1046/j.1354-1013.2002.00486.x

[12] Olson, K.R., Jones, R., Gennadiyev, A., Chernyanskii, S., Woods, W. and Lang, J. (2006) Fly-Ash Distribution to Assess Erosion and Deposition in an Illinois Landscape. Soil and Tillage Research, 89, 155-166.

https://doi.org/10.1016/j.still.2005.07.007

[13] Olson, K.R., Gennadiyev, A., Zhidkin, A., Markelov, M., Golosov, V. and Lang, J. (2013) Use of Magnetic Tracer and Radio-Cesium Methods to Determine Past Cropland Soil Erosion Amounts and Rates. Catena, 104, 103-110. https://doi.org/10.1016/j.catena.2012.10.015

[14] Hussain, I., Olson, K.R. and Jones, R. (1998) Erosion Patterns on Cultivated and Uncultivated Hillslopes Determined by Soil Fly Ash Contents. Soil Science, 163, 726-738. https://doi.org/10.1097/00010694-199809000-00006

[15] Olson, K.R., Gennadiyev, A.N., Zhidkin, A.P. and Markelov, M.V. (2011) Impact of Land Use Change and Soil Erosion in Upper Mississippi River Valley on Soil Organic Carbon Retention and Greenhouse Gas Emissions. Soil Science, 176, 449-458. https://doi.org/10.1097/SS.0b013e3182285cde

[16] Olson, K.R., Jones, R., Gennadiyev, A., Chernyanskii, S., Woods, W. and Lang, J. (2003) Soil Catena Formation and Erosion of Two Mississippian Mounds at Cahokia Archaeological Site, Illinois. Soil Science, 168, 812-824. https://doi.org/10.1097/01.ss.0000100469.96182.9c

[17] Olson, K.R., Gennadiyev, A., Jones, R. and Chernyanskii, S. (2002) Erosion Patterns on Cultivated and Reforested Hillslopes in Moscow Region, Russia. Soil Science Society of America Journal, 66, 193-201. https://doi.org/10.2136/sssaj2002.0193

[18] Staff, S.S. (2004) Soil Survey Laboratory Methods Manual: Soil Survey Investigations Report No. 42 Version 4.0. United States Department of Agriculture, Natural Resources Conservation Service, Nebraska.

[19] Salemme, R. (2015) Land-Use Change Effects on Soil Organic Carbon, Total Soil Nitrogen and Soil Erosion in a Temperate Forest and Grassland. Thesis, Graduate College of University of Illinois at Urbana-Champaign, Urbana-Champaign.

[20] Olson, K.R., Al-Kaisi M., Lal, R. and Cihacek, L. (2016) Soil Organic Carbon Dynamics in an Eroding and Depositional Landscapes. Open Journal of Soil Science, 6, 121-134. https://doi.org/10.4236/ojss.2016.68013

[21] Manies, K., Harden, J., Kramer, L. and Parton, W. (2001) Carbon Dynamics within Agricultural and Native Sites in the Loess Region of Western Iowa. Global Change Biology, 7, 545-555. https://doi.org/10.1046/j.1354-1013.2001.00427.x

[22] Lal, R. (1995) Global Soil Erosion by Water and Carbon Dynamics. In: Lal, R., Kim- 
ble, J.M., Levine, E. and Stewart, B.A., Eds., Soils and Global Change, CRC/Lewis Publishers, Boca Raton, 131-142.

[23] Lal, R. (2003) Soil Erosion and the Global Carbon Budget. Environment International, 29, 437-450. https://doi.org/10.1016/S0160-4120(02)00192-7

[24] Khan, S., Mulvaney, R., Ellsworth, T. and Boast, C. (2007) The Myth of Nitrogen Fertilization for Soil Carbon Sequestration. Journal of Environmental Quality, 36, 1821-1832. https://doi.org/10.2134/jeq2007.0099 